\title{
The Effects of Rewarding System on Employee Turnover
}

DOI: https://doi.org/10.47175/rissj.v1i3.94

\section{| John Kanyambo ${ }^{1}$ | Bogere Mohammed² |}

\author{
${ }^{1}$ Master student, School of \\ Business and Economics, \\ Mount Kenya University \\ Kigali, Rwanda \\ ${ }^{2}$ Senior lecturer, School of \\ Business and Economics, \\ Mount Kenya University \\ Kigali, Rwanda \\ *Corresponding Email: \\ gedion.impact@gmail.com
}

\begin{abstract}
This study examined the effects of retention strategies on employee turnover taking a case of Urwego Opportunity Bank in Rwanda. The specific research objectives are: to identify the effects of reward on employee turnover and to analyze the effects of training on employee turnover. A descriptive research design was used where both qualitative and quantitative approaches were adopted.The target population was 250 employees and authorities of Urwego Opportunity Bank while 138 sampled populations was calculated using Slovin's formula. The study set to use simple random sampling techniques in order to distribute research instruments. Finding on contribution indicated by regression model, a unit increase in a unit increase in Rewarding systems variable would cause an increase of $0.260(26.0 \%)$ on employee turnover at Urwego. Finding also show that Rewarding systems posted $(t=2.357)$, this was greater 1.96 and sig $=0.002$, so this clearly shows that the variable is significant since the sig value is less than 0.05.Conclusion: Employee retention strategies are statistically significant correlated with the reduction of employee turnover among workers at Urwego Opportunity BankRwanda. Important and crucial it will affect an employee's decision for leaving the organization. The study recommends that managers should provide trainings and copy with elements that stimulate the spirit of abandonment. Workers must have enough professional development workshops to ameliorate their knowledge and experience.

KEYWORDS

Rewarding system; employee turnover and employee equity model
\end{abstract}

\section{INTRODUCTION}

The term employee turnover means the proportion of workers leaving their job or companies (DeNis and Griffin, 2008). According to Cascio and Boudreaux (2008), the most of effective way to explain employee turnover is to take into consideration, voluntary departure but also new recruitment of employees .In addition, Knapp \& Mujtaba, (2010) evidenced that turnover connotes a level of personal displacement across attachment limits of a social system" and involved persons recruited by the company and those spelt out into the firm.

Fluctuation in labor market stimulated high turnover rate in modern organization including banking institutions. A study undertaken by Pearson (2010) reiterated that it is very important to attract valuable employees from competitive companies and this become a growing phenomenon among companies including banks operating in Rwanda. 
Employee turnover is still one of the growing problem and provoking constraints any banking institution would encounter. The factors affecting employee turnover of banking Industries in Rwanda will be the subject of our discussion in this research proposal in which we have chosen Urwego Opportunity Bank as our case study. The research sought to determine elements leading to employee turnover in UOB and the policy strategies needed to be put into place.

These expenses include treatment of job vacancy files, loss of productivity from vacant and expenses related to capacity building for new employees and the increase of operational and maintenance expenditure (Robbins and Judge, 2013). The higher rate of turnover is more likely to affect negatively corporate financial institutions and economic development or growth for any country. This has now become a threat both to the employers and newly employed graduates entering the job market whom the experienced employees are supposed to passed down the knowledge and skills to them (Vance,2012). Marvelous and incredible employee turnover for banks in the current days, lead to the consideration of awareness of its factors, causes and effects. It is therefore, the present research was seeking to assess factors leading to high rate of turnover among people working in banking institutions in Rwanda with focused attention on Urwego Opportunity Bank in Rwanda.

\section{REVIEW OF LITERATURE}

This paper attempts to relate some of the factors discovered to major theories such as the Employee Equity Model. The literature surveyed by this study mention employee motivation, job satisfaction and job embeddedness as the main factors that influence employee retention rates. The study proposes that job embeddedness is a superior model that significantly explains employee retention

Employee Equity Model Al-Zawahreh and Al-Madi ,(2017) observed that equity theory is gaining deserved popularity in the human resource departments as it ensures fair results for both the employer and the employee. Equity theory can be illustrated using an example from Tolman's monkeys (Bell, 2011, p.4). This model emulates, monkeys receive a reward for good behavior in the form of bananas or monkey chow. However, when they expected to be rewarded with bananas but got monkey chow instead, they felt cheated. Bell (2011) equates this example with feelings of inequity at the workplace (p.4). Equity is a major issue for government, labor, and industry. In any given situation, equity theory is applicable especially given that there is usually a form of exchange; for instance, between couples, teammates, or employer and employee.

\section{Identification of the Effects of Rewarding System on Employee Turnover}

According to Dormio (2005) and Aydogdu (2011) investigated the influence of historical background of employment and indicate employment opportunities related to the employee turnover. The above researcher demonstrated a clear awareness on the correlation between employment contentment, organization willingness and the need of employee turnover and the effect of company, socialization and capacity development in retaining employees. A research undertaken by Guyo (2011) evidenced that appropriate strategies for retaining employees, the provision of rewards and recognition and unfavorable working conditions are more like to affect the employee turnover rate. Newaz (2007) carried out a research on the perception of the roots that leas employee to abandon their position and other to be recruited and how turnover from position to position. 


\section{Herzberg's Theory}

Herzberg's two-factor theory of motivation is widely known in management circles. However, it has been criticized regarding its validity in different work settings. Construction is an industry with unique characteristics which may have special effects on employee motivation. This study underpins the two-factor theory as indicated on (Maidani, 2017).

\section{Rewarding System and Employee Turnover}

According to Dormio (2005) and Aydogdu (2011) investigated the influence of historical background of employment and indicate employment opportunities related to the employee turnover. The above researcher demonstrated a clear awareness on the correlation between employment contentment, organization willingness and the need of employee turnover and the effect of company, socialization and capacity development $v$ in retaining employees. A research undertaken by Guyo (2011) evidenced that appropriate strategies for retaining employees, the provision of rewards and recognition and unfavorable working conditions are more like to affect the employee turnover rate. Newaz (2007) carried out a research on the perception of the roots that leas employee to abandon their position and other to be recruited and how turnover from position to position

\section{Types of Turnover}

Scientific evidences argue that two types of employee turnover are voluntary and involuntary turnover. In this regards, voluntary turnover happened when workers abandon an organization due to its own creativity and inventiveness without company's willingness. This type argues that workers who abandon his/her job due to the intention of having adequate job prospects, job environment, rewards, recognition, pension, health related causes, adjustment of positions, and shifting families (African Journal of Business Management, 2010) However, even if a company did not have workers they requested and could not prevent or monitor the employee departure, and negative conditions that a company have (Chepkilort, 2005).

\section{RESEARCH METHODS}

\section{Research Design, Population, Sampling Techniques and Data Collection Procedures}

A descriptive research design was adopted to carry out the present researcher due to its importance in forecasting, predicting, narrating facts and evidences from respondents. Creswell and Vicki (2007) described a research design as plan or a way concerning methods and steps for collecting information and information analysis. The target population for this research was 250 employees working at Urwego Opportunity Bank.

A total number of employees is 250 where the sample size is obtained from the used of Morgan Krejcie Table (1970). In this regards, the sample size is 150 employees. The intention to ensure statistical representation, effective method of calculating sample size is adopted. In order to overcome challenges related to representation and generalization, the sample size was determined by using Slovin formula as developed by sevella, ochave, Creswell and Plano (2010).

The sample size was determined by using Slovin formula as developed by sevella, ochave, Creswell and Plano (2010). 


$$
n=\frac{N}{1+N^{*}(e) 2}
$$

Where $\mathrm{n}=$ sample size; $\mathrm{N}=$ population size and $\mathrm{e}=$ Margin error which is equal to 0.05 for the case of research. Using this formula $\mathrm{N}=250 ; \mathrm{e}=0.05 ; \mathrm{n}=\frac{250}{1+250(0.05)^{2}}$

Questionnaires were administered to sampled respondents and were used as methods for data collection; they were written in English and the researcher attempted to explain to the respondents in their mother tongue. Research questionnaire were constructed according to the specific research objectives by considering indicators given in the conceptual framework.

\section{Data Collection Tools and Procedures}

A descriptive survey design was employing Questionnaires and interviews were used to collect primary data. A descriptive research approach was carried out by use of participatory questionnaires

Questionnaires were administered to sampled respondents and were used as methods for data collection; they were written in English and the researcher attempted to explain to the respondents in their mother tongue Interview guide was used while interviewing human resources officers and managers of sub branches of Urwego Opportunity Bank in order to have deep information related to the research subjects with open ended as well as close questions.

The sample size was calculated through the use of Krejcie \& Morgan's (Creswell, 2009) formula of determining sample size

$$
n=\frac{N}{1+N^{*}(e) 2}
$$

Where $\mathrm{n}=$ sample size; $\mathrm{N}=$ population size and $\mathrm{e}=$ Margin error which is equal to 0.05 for the case of research.

\section{Validity, Pilot and Reliability of Instruments}

\section{Pilot of Instruments}

Pilot studies were done to pretest the research instrument such as the questionnaire (2014). A pilot study intends to get rid of in advance, some of the problems that are expected to be encountered during the ultimate study (Cooper, 2006). Korb (2012) asserts that split test is the important reliability of evidence for questionnaires. The pilot was done at the Ministry of Local Government (MINALOC) and will be done at 50\% equivalent of the study sample size.

\section{Reliability of Research Instrument}

Reliability is defined as a consistency in repeating measurements and indicators through the generation of similar outcome across time and across observations from different people while validity means the performance of any research in assessing what the author formulated to evaluate for objective of testing validity of questionnaire

\section{RESULTS AND DISCUSSION}

\section{Normality, Skewness and Kurtosis}

Skewness refers to the symmetry of a distribution, that is, a variable whose mean is not in the center of the distribution is regarded as a skewed variable, whereas kurtosis relates to 
the peakedness of a distribution (Tabachnick \& Fidell, 2014). A distribution is said to be normal when the values of skewness and kurtosis are equal to zero (Tabachnick \& Fidell, 2014). If the kurtosis is positive then the distribution is more peaked than normal distribution, while a negative value would indicate a more flat distribution than a normal distribution.

Hair et al. (2010) suggest use of P-P plots to check the relationship (Liner) between study variables. The plotted points need to be close to the ideal line for linearity to exist

\section{Normality of Data}

The application of multivariate analysis including SEM, depends heavily on the assumption of normality (Kline, 2016). Normality refers to the shape of data distribution for an individual metric variable, and its correspondence to the normal distribution (Hair et al., 2010).

\section{Table 1. Test of Hypothesis}

H02: Rewarding system has no statistical on employee turnover at Urwego Opportunity Bank-Rwanda

The results in the table above, indicates that Rewarding systems is $\mathrm{t}=2.357$, which is more than 1.96 and that sig $=0.002$ is greater than 0.05 this explains that this variable is significant .The null hypothesis is rejected and alternate was accepted.

\begin{tabular}{|l|l|l|}
\hline Hypotheses & Hypotheses tests & Decision rule and regression model \\
\hline HO1: Rewarding & $\operatorname{Beta}$ test $(\beta)$ & ET $=\alpha+\beta_{2} \mathrm{RT} \alpha+\varepsilon$ \\
systems no & $\mathrm{HO}_{1}: \beta=0$ & Where \\
significance & $\mathrm{HA}_{1}: \beta_{\neq} 0$ & $\alpha:-$ Y Intercept \\
influence on & conduct a t-test to & $\beta:-$ Regression coefficient \\
Employee & determine the significance & ET : - Employee Turnover \\
Turnover & effect of Rewarding systems & $\mathrm{RS}:-$ Rewarding systems \\
& on Employee Turnover & $\beta_{1}=0:$ Accept Ho if $\beta_{6}$ is $\leq \alpha$ \\
& & $\beta_{\neq} 0:$ Reject Ho if $\beta_{6}$ is $\geq \alpha$ \\
\hline
\end{tabular}

Table 2. Skewness and Kurtosis

\begin{tabular}{|l|l|l|l|}
\hline Variables & N & Skewness & Kurtosis \\
\hline Compensation & 138 & 0.512 & 0.082 \\
\hline Rewarding systems & 138 & 0.190 & 0.0663 \\
\hline Training & 138 & 0.607 & 0.0521 \\
\hline
\end{tabular}

Finding in .2) Skewness and Kurtosis Considering the skewness "If skewness is less than

-1 or greater than 1 , the distribution is highly skewed. If skewness is between -1 and -0.5 or between 0.5 and 1 , the distribution is moderately skewed. If skewness is between -0.5 and 0.5 , the distribution is approximately symmetric." (spcforexcel, 2008).

In the above table skewness value for Compensation is 0.512 ; for Rewarding systems, the skewness value is 0.190; and for Training, the skewness value is 0.607 ; Finally, the study considers the values only Training value (skewness $=0.607$ ) is moderately skewed and the two variables (Compensation and Rewarding systems ) values fall in between 0.5 and 0.5 which means that data distribution is approximately symmetric. However, Kurtosis means the near its value is to 0 the better the data distribution, the values for 
kurtosis the table 4.3 for Compensation is 0.082 ; for Rewarding systems it's 0.0663 ; and for Rewarding systems it's 0.0521. Finally, these study findings indicate that all variables fall in-between +1 and -0 so it means that the data is well distributed.

\section{Evaluation of Rewarding System and Reduction of Employee Turnover}

The researcher further evaluated dependent variable to see if its indicators was influence by rewarding system at Urwego Opportunity Bank as shown in the table below

\section{Evaluation of Rewarding System and Reduction of Employee Turnover}

Findings in show that a high level of agreement in rewarding system at Urwego Opportunity Bank. Furthermore, $50.0 \%$ of respondents agree that the dismissal was reduced was achieved at Urwego Opportunity Bank. Moreover, 32.5\% of respondents agreed that employees at Urwego Opportunity Bank, did not tend to resign and this reduced the number.

\section{Assessment of Rewarding System and Employee Turnover at Urwego Opportunity}

The author sought to identify the effects of reward system on employee turnover at Urwego Opportunity Bank-Rwanda. The second objectives established evidences on the recognition certificate for employee performance appraisal, the importance of appreciation for employee work by top management and co-workers, fair treatment and respect from supervisors, bonus received at the end of the year, and supervisor acknowledge of employee performance. Based on the above finding, the researcher analyzed data using a correlation approach to verify the attainment of the second specific objectives towards the dependent variable. The Pearson correlation test was conducted on the rewarding system to determine the significance of reward system and their influence on employee turnover. The study required $\mathrm{P}$ value ranged between 0.00 and 0.05 for significant factors.

Table 3. Correlation between Rewarding System and Employee Turnover

Rewards system Correlations

The fair treatment and respect from supervisors

$-.556 ” .000$

The bonus received at the end of the year, and supervisor $.745 " .000$ acknowledge of employee performance

Source: Primary Data (2019)

Results reflected in (Table.3) shows that using Rewarding system is positively correlated with encouragement and retention of workers with an organization at $\mathrm{p}$ value $=$ 0.000. The recognition certificate for employee performance appraisal was significant $(\mathrm{P}=0.007)$. The paramount role of appreciation for employee work by top management and co-workers is associated with reduction of turnover at $\mathrm{p}$ value $=0.000$. The unbiased treatment or respect from supervisors of it was significant $(\mathrm{P}=0.000)$. Finally, the bonus received at the end of the year, and supervisor acknowledge of employee performance was significant (Pearson correlation model of $r=0.745$ " and p.000). 


\section{CONCLUSION}

Research indicated that Urwego Opportunity Bank recognized a favorable rewarding system that is able to retain them and to reduce employeeturnover.Obviously,workers evidenced a positive perception towards how the bank is treating them. The researcher concluded that Urwego Opportunity Bank use adequate retention strategies helps in improving employee satisfaction and then low level of employee turnover and these methods are employee suitable compensation policies, appropriate rewarding system and compensation and staff training and career development.

\section{Recommendations}

As the research indicated that workers in some instance are constrained by lack of skills, banks should provide trainings and copy with elements that stimulate the spirit of abandonment. Managers should be given training to improve their management style, as most individuals indicated that they are not valued in their institutions. Regular survey should be conducted to establish employee-needs as well as to measure their perceptions regarding their jobs and the organisation they are working for. Feedback should be given to employees regarding the result of this survey.

The research proposed that workers must have enough professional development workshops to ameliorate their knowledge and experience due to the ability of capacity building in optimizing and retaining people within an institution to provide their adequate skills to enhance organizational profitability.

Workers must have enough professional development workshops to ameliorate their knowledge and experience. Further research should investigate other sectors than banking sector and they should involve workers who did not leave their working place and who will bring additional information concerning the tendency to abandon the organization but also to establish suitable approaches to retain workers.

\section{REFERENCES}

Cascio, W. F. (2007). Managing Human Resources: Productivity, Quality of Work Life, Profits (Seventh Edition). New Delhi: Tata McGraw Hill Publishing Company Limited.

Creswell, J. W. and Plano C. (2010). Designing and Conducting Mixed Methods Research. (2nd Ed.). London, UK: Sage Publishers.

Creswell, J.W. (2011). Research Design: Qualitative, Quantitative, and Mixed Methods Approaches. (Third Edition). New Delhi: SAGE Publications India Pvt. Ltd.

DeCenzo, D.A and Robbins, S.P.(2005). Fundamentals of Human Resource Managemen. John Wiley and Sons Inc.

Dei, E and Ryan,R.(2009). Self-determination Theory: A consideration of human motivation. The Cambridge Handbook of personal psychology .New York. Cambridge University Press.

Dwomo, G. (2012).The relationship between employee voice and organizational performance of Electricity Company of Ghana. European Journal of Management, 4(6), $1-6$.

Leiter, MP and Maslach, C (2009). 'Nurse Turnover: The mediating role of burnout', Journal of Nursing Management, vol. 17, no. 3, pp. 331-9.

Uzona, U. R. (2013). Impact of Motivation on Employees Performance: A Key Study of Credit West Bank Cyprus. Academy of Management Journal, 15, 2-29. 
Vance, R (2012). Employee Engagement and Commitment, A guide to understanding, measuring and increasing engagement in your organization York, NY: Thompson South-Western.

Gymfi, G.G.(2015). Assessment of the relationship between employee motivation and Employee performance at a bank in Ghana. International Journal of Economics, Commerce and Management, Vol III,Issue 3:1-15 